\title{
Soil based nutrient management plan for Onattukara sandy tract of Kerala
}

\section{MINI AND USHA MATHEW}

MEMBERS OF RESEARCH FORUM

Corresponding author :

V. MINI, Department of Soil Science and Agricultural Chemistry, College of Agriculture (K.A.U.), Vellayani, TRIVANDRUM (KERALA) INDIA

Email: minisvilas@gmail.com

Co-authors :

USHA MATHEW, Department of Soil Science and Agricultural Chemistry, College of Agriculture (K.A.U.), Vellayani, TRIVANDRUM (KERALA) INDIA
Received : 20.01.2015; Revised : 28.04.2015; Accepted : 07.05.2015

\section{Summary}

The present investigation was carried out at College of Agriculture, Vellayani, Kerala Agricultural University, Kerala to develop the nutrient management strategies for Onattukara sandy tract of Kerala. The overall fertility status of this region indicated that the soil was strongly acidic with high level of phosphorus and low organic carbon and potassium. Excess levels of phosphorus and wide spread deficiencies of calcium, magnesium boron and zinc are the major limitations to crop production in this region. Management of soil acidity is essential for successful crop production in the region. Liming of acid soils in accordance with soil test results is highly essential. Regular application of organic matter or recycling of organic matter is essential to maintain favourable physico-chemical and biological environment in the soils and retention of applied plant nutrients. Restrict the use of nitrogenous (N) fertilizers in accordance with soil test results or as recommended in the package of practices of Kerala Agricultural University. Reduction in the use of phosphatic $(\mathrm{P})$ fertilizers to the tune of fifty per cent of the recommended dose is possible. Apply potassium (K) fertilizers in doses specified, but in several splits to minimize the leaching losses. Amelioration of soil acidity and external inputs of secondary and micronutrients along with the NPK nutrients are essential for enhancing crop productivity in the region.

Key words : Coconut, Cropping system, Nutrient management plan, Onattukara, Sandy tract

How to cite this article : Mini, V. and Mathew, Usha (2015). Soil based nutrient management plan for Onattukara sandy tract of Kerala. Asian J. Soil Sci., 10(1) : 99-103. 